OPEN ACCESS

Edited by:

Hany M.R. Abdel-Latif, Alexandria University, Egypt

Reviewed by: Mahmoud M. Alagawany,

Zagazig University, Egypt Mustafa Shukry,

Kafrelsheikh University, Egypt Sevdan Yilmaz,

Canakkale Onsekiz Mart

University, Turkey

*Correspondence:

Liansheng Wang

wangliansheng@hrfri.ac.cn

Specialty section:

This article was submitted to Nutrition and Sustainable Diets,

a section of the journal

Frontiers in Nutrition

Received: 13 April 2021

Accepted: 17 June 2021

Published: 13 July 2021

Citation:

Fan Z, Li J, Zhang Y, Wu D, Zheng X, Wang $C$ and Wang $L$ (2021) Excessive

Dietary Lipid Affecting Growth Performance, Feed Utilization, Lipid

Deposition, and Hepatopancreas

Lipometabolism of Large-Sized

Common Carp (Cyprinus carpio).

Front. Nutr. 8:694426.

doi: 10.3389/fnut.2021.694426

\section{Excessive Dietary Lipid Affecting Growth Performance, Feed Utilization, Lipid Deposition, and Hepatopancreas Lipometabolism of Large-Sized Common Carp (Cyprinus carpio)}

\author{
Ze Fan, Jinnan Li, Yuanyuan Zhang, Di Wu, Xianhu Zheng, Chang'an Wang and \\ Liansheng Wang *
}

Key Laboratory of Aquatic Animal Diseases and Immune Technology of Heilongjiang Province, Heilongjiang River Fisheries
Research Institute, Chinese Academy of Fishery Sciences, Harbin, China

An 82-day study was conducted to assess the effect of the dietary lipid levels on growth performance, feed utilization, lipid deposition, and hepatopancreas lipometabolism of large-sized common carp (Cyprinus carpio). Six isonitrogenous (300 g/kg protein) pelletized diets with different dietary lipid levels (30,60, 90, 120, 150, and $180 \mathrm{~g} / \mathrm{kg}$ ) were fed in triplicate to fish groups with 75 individuals (with an initial mean weight of $247.00 \pm 16.67 \mathrm{~g}$ ). The results showed that there was a significant increase in weight gain (WG) rate (WGR), specific growth rate (SGR), and protein efficiency ratio (PER) as dietary lipid levels increased from 30 to $60 \mathrm{~g} / \mathrm{kg}(\rho<0.05)$ and then there was a decline. Feed conversion rate (FCR) was observed to be significantly lower in 60 $\mathrm{g} / \mathrm{kg}$ lipid treatments $(p<0.05)$. Muscle crude protein contents were obtained to be significantly higher in 60 and $90 \mathrm{~g} / \mathrm{kg}$ treatments $(p<0.05)$. The crude lipid content in the hepatopancreas increased significantly with an increase in dietary lipid levels $(p<0.05)$. The expression of lipoprotein lipase (LPL) and carnitine palmitoyltransferase-1 (CPT1) in the hepatopancreas was significantly downregulated with an increase in dietary lipid levels while the expression of growth hormone $(\mathrm{GH})$, insulin-like growth factor-1 (IGF-1), fatty acid synthase (FAS), acetyl-CoA carboxylase-1 (ACC-1), and sterol regulatory element binding protein (SREBP) was upregulated first in 30 and $60 \mathrm{~g} / \mathrm{kg}$ lipid treatments and then downregulated significantly in other treatments. The results revealed that excess dietary lipid supplements (more than $60 \mathrm{~g} / \mathrm{kg}$ ) would inhibit WG and would aggravate the lipid decomposition in the hepatopancreas. Based on WGR and FCR, the dietary lipid levels of 59.5 and $70.4 \mathrm{~g} / \mathrm{kg}$ were optimal for growth performance and feed utilization of large-sized common carp.

Keywords: common carp, lipid requirement, growth performance, lipid deposition, hepatopancreas lipometabolism 


\section{INTRODUCTION}

For decades, the exploration of an approach to minimizing the dietary protein consumption and simultaneously maximizing the protein utilization efficiency has been extremely imperative for the sustainable development of the aquaculture feed industry (13). Investigators have begun to perform feasibility studies on the protein-sparing effect of lipids in fish diets (4-7). In addition to the prominent protein-sparing effect, the traditional functions of lipids involve the provision of high energy values, promotion of the absorption of fat-soluble vitamins, inhibition of dust, improvement of the palatability, etc., which are important for the feed industry (8). Moreover, from a fish nutrition perspective, dietary lipids play a crucial role in furnishing essential fatty acids, phospholipids, sterols, and fat-soluble vitamins and maintaining the stability of biological structures and cell membrane functions (9-11). If a shortage occurs in dietary lipid supplements, then metabolic disturbance may be observed in fish along with a decrease in the efficiency of feed protein and the lack of fatsoluble vitamins and essential fatty acids (12). Thus, there has been a visible tendency to supply higher concentration of lipids in commercial diets.

However, high concentrations of lipids have been included in commercial diets, which have created controversy among some researchers and fish farmers (13). Excess dietary lipid supplements could bring about a diminution in feed consumption or feed ingestion rate by fish, thereby limiting the growth performance of the farmed fish (14). Moreover, there are misgivings on the fact that an excessive amount of dietary lipid could increase fat deposition in the liver and muscle, thereby affecting the flavor and nutritional qualities of the product $(15,16)$. Meanwhile, for many other fish species, an excess of dietary lipids could contribute to oxidative stress, accompanied by negatively affecting survival, growth, disease resistance, stress response, and lipid metabolism (17). In addition, for fish, the dietary lipid requirement varies distinctly with different species, body weights, life stages, and environmental conditions (18). Under such circumstances, appropriate dietary lipid supplements for different fish species should be confirmed to ensure optimal growth and production quality and to prevent dietary protein from being used as energy.

Common carp (Cyprinus carpio), with the strong adaptive capability to both environment and food $(19,20)$, is commercially important (21) and represents the third most widely cultivated freshwater fish species in the globe (22). The common carp production in 2018 was 2,962,218 tons in China, which ranked at the fourth position out of a total of 25 species evaluated (23). However, to our knowledge, the available information on the dietary lipid requirement for common carp was limited to juvenile common carp with the body weights below $20 \mathrm{~g}$ and on growing common carp with the weights ranging from 20 to $100 \mathrm{~g}(24)$. Xu et al. (24) obtained the results from the study on common carp [an initial body weight (IBW) of 5.51 $\pm 0.05 \mathrm{~g}$ ] in which the optimum dietary lipid requirement of juvenile common carp was $8 \%$ at $16^{\circ} \mathrm{C}$ and $11 \%$ at $23^{\circ} \mathrm{C}$ in terms of immunity. When the weight of common carp reached $15 \mathrm{~g}$, a diet of them containing $80 \mathrm{~g} / \mathrm{kg}$ lipids was optimal for growth performance and health status (25). Additionally, juvenile common carp with an IBW of $105 \mathrm{~g}$ showed the best growth performance with the dietary lipid level of $44 \mathrm{~g} / \mathrm{kg}$ (26). However, knowledge of the dietary lipid requirements of common carp with an IBW of more than $200 \mathrm{~g}$ is limited, and the detailed studies on this topic are currently lacking. Regarding the current situation, with an aim to optimize the dietary lipid requirement of large-sized common carp of more than $200 \mathrm{~g}$ and further strengthen the precise nutrition regulation in the breeding process of common carp, the effects of practical diets with different lipid contents on growth performance, body composition, and hepatopancreas lipometabolism of large-sized common carp were evaluated.

\section{MATERIALS AND METHODS Preparation of Feedstuff and Chemical Reagent}

Fish meal (crude protein, $670 \mathrm{~g} / \mathrm{kg}$ diet and crude lipid, 100 $\mathrm{g} / \mathrm{kg}$ diet), soybean meal (crude protein, $440 \mathrm{~g} / \mathrm{kg}$ diet and crude lipid, $15 \mathrm{~g} / \mathrm{kg}$ diet), and wheat middlings (crude protein, $130 \mathrm{~g} / \mathrm{kg}$ diet and crude lipid, $12 \mathrm{~g} / \mathrm{kg}$ diet) were purchased from Hehe Feed Co., Ltd (Dongguan, China). Soybean oil was purchased from Jiusan Oils \& Grains Industries Group Co., Ltd. (Heilongjiang, China).

Hydrochloric acid (analytical reagent, AR), sulfuric acid (AR), copper sulfate pentahydrate, potassium sulfate (AR), sodium hydroxide (AR), boric acid (AR), ammonium sulfate (AR), methyl red, bromocresol green, and anhydrous ethanol were obtained from Sinopharm Chemical Reagent Co., Ltd. (Shanghai, China). Petroleum ether $\left(40-60^{\circ} \mathrm{C}\right)$ for the determination of crude lipid in the diets, whole body, dorsal white muscle, and hepatopancreas was obtained from Sinopharm Chemical Reagent Co., Ltd. (Shanghai, China).

\section{Feed Formulation and Preparation}

Diet ingredients and compositions supplied to common carp are listed in Table 1. Six dietary treatments containing six lipid levels of $30,60,90,120,150$, and $180 \mathrm{~g} / \mathrm{kg}$ were formulated according to the National Research Council (NRC) (11) (Table 1). Fish meal and soybean meal were regarded as protein sources. Soybean oil was regarded as the lipid source. As the lipid level rose, the content of wheat middling decreased correspondingly to maintain the energy content. Carboxymethylcellulose sodium (CMC-Na) and cellulose were treated as a filler. The dry feed ingredients were ground with a grinder and sieved, weighed, and thoroughly mixed in a horizontal mixer (SLHY-1, Dashiqiao Bao's Feed Machinery Factory, Yingkou city, Liaoning Province, China). Soybean oil, CMC, and cellulose were appended and adequately blended to make dough, and vitamin-mineral premixes and trace mineral premix were appended. Moist diets were made into 3-mm-sized pellets by a pelletizer (GYJ-250B, Dashiqiao Bao's Feed Machinery Factory). The dry diets were stored at $-20^{\circ} \mathrm{C}$ until their use. 
TABLE 1 | Ingredients and proximate composition of experimental diets ( $\mathrm{g} / \mathrm{kg}$ of dry matter basis).

\begin{tabular}{|c|c|c|c|c|c|c|}
\hline \multirow[t]{2}{*}{ Ingredients $^{\mathrm{a}}$ (g/kg) } & \multicolumn{6}{|c|}{ Experimental diets } \\
\hline & 30 g/kg & $60 \mathrm{~g} / \mathrm{kg}$ & $90 \mathrm{~g} / \mathbf{k g}$ & $120 \mathrm{~g} / \mathrm{kg}$ & $150 \mathrm{~g} / \mathrm{kg}$ & $180 \mathrm{~g} / \mathrm{kg}$ \\
\hline Soybean meal & 550 & 550 & 550 & 550 & 550 & 550 \\
\hline Wheat middling & 310 & 280 & 250 & 220 & 190 & 190 \\
\hline Fish meal & 50 & 50 & 50 & 50 & 50 & 50 \\
\hline Soybean oil & 15 & 45 & 75 & 105 & 135 & 165 \\
\hline Carboxymethylcellulose sodium (CMC-Na) & 10 & 10 & 10 & 10 & 10 & 10 \\
\hline Choline chloride & 5 & 5 & 5 & 5 & 5 & 5 \\
\hline Dicalcium phosphate & 25 & 25 & 25 & 25 & 25 & 25 \\
\hline Vitamin premix ${ }^{a}$ & 3 & 3 & 3 & 3 & 3 & 3 \\
\hline Trace mineral premix ${ }^{b}$ & 2 & 2 & 2 & 2 & 2 & 2 \\
\hline Cellulose & 150 & 120 & 90 & 60 & 30 & 0 \\
\hline \multicolumn{7}{|l|}{ Proximate composition } \\
\hline Crude protein & 300.2 & 298.9 & 300.3 & 299.7 & 299.1 & 300.1 \\
\hline Crude lipid & 30.5 & 60.6 & 90.4 & 121.3 & 152.5 & 178.9 \\
\hline Crude ash & 67.6 & 67.4 & 68.3 & 68.6 & 68.1 & 67.7 \\
\hline Carbohydrate (NFE) ${ }^{c}$ & 409.95 & 393.45 & 376.95 & 360.45 & 343.95 & 343.95 \\
\hline Estimated gross energy/(kcal/100 g $)^{d}$ & 366.12 & 386.93 & 409.26 & 430.46 & 451.66 & 480.54 \\
\hline
\end{tabular}

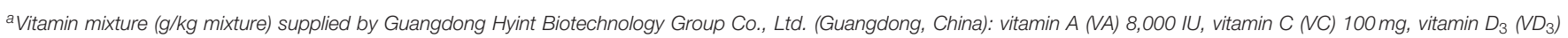
$3,000 \mathrm{IU}$, vitamin $E(N E) 60 \mathrm{mg}$, vitamin $K_{3}\left(N K_{3}\right) 5 \mathrm{mg}$, vitamin $B_{1}\left(N B_{1}\right) 15 \mathrm{mg}$, vitamin $B_{2}\left(N B_{2}\right) 30 \mathrm{mg}$, vitamin $B_{6}\left(V B_{6}\right) 15 \mathrm{mg}$, and vitamin $B_{12}\left(N B_{12}\right) 0.5 \mathrm{mg}$.

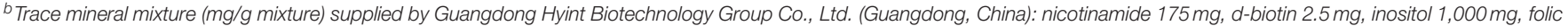
acid $5 \mathrm{mg}$, pantothenic acid $50 \mathrm{mg}$, zinc (Zn) $60 \mathrm{mg}$, copper (Cu) $3 \mathrm{mg}$, iron (Fe) 25 mg, manganese (Mn) $15 \mathrm{mg}$, iodine (I) $0.6 \mathrm{mg}$, and magnesium (Mg) $0.7 \mathrm{mg}$.

${ }^{c} N F E$, Nitrogen-free extract.

${ }^{d}$ Estimated gross energy/ (kcal/100 g) $=(4 \times$ crude protein \% $)+(9 \times$ lipid \% $)+(4 \times$ carbohydrate \%).

TABLE 2 | Primers used for the quantitative reverse transcriptase -PCR (qRT-PCR).

\begin{tabular}{|c|c|c|c|}
\hline Gene name & Primer sequence $\left(5^{\prime}-3^{\prime}\right)$ & Product size (bp) & Accession number \\
\hline IGF-12 & F: AGACAGCCCAAGGACAGCA; R: TACAGTGGAGCACATCTCTGGAA & 204 & HM565013.1 \\
\hline $\mathrm{LPL}^{4}$ & F:CGCTCCATTCACCTGTTCAT; R:GCTGAGACACATGCCCTTATT & 105 & FJ716101.1 \\
\hline $\mathrm{CPT}-1^{5}$ & F:CAGATGGAAAGTGTTGCTAATGAC; R:TGTGTAGAAGTTGCTGTTGACCA & 168 & JQ361077.1 \\
\hline SREBP 6 & F:CGTCTGCTTCACTTCACTACTC; R:GGACCAGTCTTCATCCACAAA & 141 & XM_019073316.1 \\
\hline$\beta$-actin & F:GGCAGGTCATCACCATCGG; R:TTGGCATACAGGTCTTACGG & 107 & M24113.1 \\
\hline
\end{tabular}

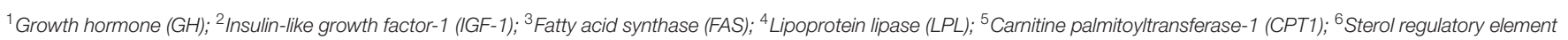
binding protein (SREBP); and ${ }^{7}$ Acetyl-COA carboxylase-1 (ACC-1).

\section{Fish Rearing}

The feeding trial was carried out in the floating net cages $(2 \times 2$ $\times 2 \mathrm{~m}$ ) in Hulan Experimental Station of Heilongjiang Fisheries Research Institute (Harbin, China). Large-sized common carp were also obtained from the Hulan Experimental Station of Heilongjiang Fisheries Research Institute (Harbin, China), and were fed with a commercial diet $(320 \mathrm{~g} / \mathrm{kg}$ crude protein and 60 $\mathrm{g} / \mathrm{kg}$ crude lipid) for 2 weeks before the feeding trial to acclimate to the experimental conditions. Prior to the beginning of the feeding trial, six triplicate groups of fish with healthy status and of uniform size (25 individuals per replicate with an initial mean weight of $247.00 \pm 16.67 \mathrm{~g}$, 1 year of age) were randomly assigned into the floating net cages, respectively. Throughout the 82-day feeding trial, the diets were provided to the fish at the rate of 3-4\% of the body weight thrice at 8:00 a.m., 13:00 p.m., and 17:30 p.m. every day for 82 days. Meanwhile, the water temperature $\left(28-32^{\circ} \mathrm{C}\right)$, total ammonia $(0-0.20 \mathrm{mg} / \mathrm{L})$, and dissolved oxygen $(5.8-6.2 \mathrm{mg} / \mathrm{L})$ were monitored daily. All water quality parameters were determined by using a multi-parameter water quality analyzer (HQ40D) (HACH Company, Loveland, CO, USA).

\section{Calculations of Growth Indexes and Sampling}

All fishes in the cage were weighed and counted to assess the survival rate (SR), weight gain (WG), feed conversion rate (FCR), 
TABLE 3 | Growth performance and feed utilization of large-sized common carp fed the diets containing different lipid levels .

\begin{tabular}{|c|c|c|c|c|c|c|}
\hline \multirow[t]{2}{*}{ Items } & \multicolumn{6}{|c|}{ Varying levels of dietary lipid } \\
\hline & $30 \mathrm{~g} / \mathbf{k g}$ & $60 \mathrm{~g} / \mathrm{kg}$ & $90 \mathrm{~g} / \mathbf{k g}$ & $120 \mathrm{~g} / \mathrm{kg}$ & $150 \mathrm{~g} / \mathrm{kg}$ & $180 \mathrm{~g} / \mathrm{kg}$ \\
\hline $\mathrm{IBW}^{1}$ & $236.67 \pm 3.52$ & $242.67 \pm 12.67$ & $260.67 \pm 12.02$ & $241.33 \pm 8.67$ & $258.67 \pm 10.97$ & $242.00 \pm 4.62$ \\
\hline $\mathrm{FBW}^{2}$ & $587.69 \pm 8.14^{b c}$ & $668.59 \pm 34.67^{a}$ & $651.74 \pm 26.39^{a b}$ & $583.92 \pm 7.87^{c}$ & $610.17 \pm 18.19^{a b c}$ & $556.07 \pm 8.69^{c}$ \\
\hline $\mathrm{SR}^{3}$ & $100.00 \pm 0.00$ & $98.67 \pm 1.33$ & $100.00 \pm 0.00$ & $98.67 \pm 1.33$ & $100.00 \pm 0.00$ & $98.67 \pm 1.33$ \\
\hline WGR $^{4}$ & $148.33 \pm 0.61^{b}$ & $175.53 \pm 1.32^{\mathrm{a}}$ & $150.17 \pm 5.31^{b}$ & $142.37 \pm 10.11^{b c}$ & $136.17 \pm 6.79^{\mathrm{cd}}$ & $129.82 \pm 2.00^{d}$ \\
\hline $\mathrm{PER}^{5}$ & $1.70 \pm 0.07^{a}$ & $1.74 \pm 0.07^{a}$ & $1.67 \pm 0.08^{a}$ & $1.54 \pm 0.02^{b}$ & $1.52 \pm 0.02^{\mathrm{b}}$ & $1.38 \pm 0.03^{c}$ \\
\hline $\mathrm{SGR}^{6}$ & $1.11 \pm 0.00^{\mathrm{b}}$ & $1.24 \pm 0.01^{a}$ & $1.12 \pm 0.03^{b}$ & $1.08 \pm 0.05^{b c}$ & $1.05 \pm 0.03^{\mathrm{cd}}$ & $1.02 \pm 0.01^{d}$ \\
\hline $\mathrm{Fl}^{7}$ & $8.96 \pm 0.23^{b}$ & $9.84 \pm 0.42^{a}$ & $9.47 \pm 0.25^{\mathrm{ab}}$ & $9.38 \pm 0.15^{\mathrm{ab}}$ & $9.11 \pm 0.08^{a b}$ & $8.92 \pm 0.01^{b}$ \\
\hline $\mathrm{FCR}^{8}$ & $2.10 \pm 0.05^{b c}$ & $1.91 \pm 0.04^{d}$ & $1.99 \pm 0.06^{\mathrm{cd}}$ & $2.17 \pm 0.05^{b}$ & $2.19 \pm 0.02^{b}$ & $2.40 \pm 0.03^{a}$ \\
\hline $\mathrm{HSI}^{9}$ & $1.67 \pm 0.23^{b}$ & $1.73 \pm 0.21^{a b}$ & $1.97 \pm 0.21^{\mathrm{ab}}$ & $1.89 \pm 0.24^{\mathrm{ab}}$ & $2.03 \pm 0.27^{a b}$ & $2.44 \pm 0.23^{a}$ \\
\hline $\mathrm{CF}^{10}$ & $3.06 \pm 0.12^{b}$ & $3.18 \pm 0.11^{\mathrm{ab}}$ & $3.11 \pm 0.13^{\mathrm{ab}}$ & $3.09 \pm 0.13^{b}$ & $3.59 \pm 0.28^{a}$ & $3.43 \pm 0.10^{\mathrm{ab}}$ \\
\hline
\end{tabular}

"Values are the mean $\pm S D(n=3)$ of three replicates. Values within the same row with different small letters in superscript are significantly different ( $p<0.05)$.

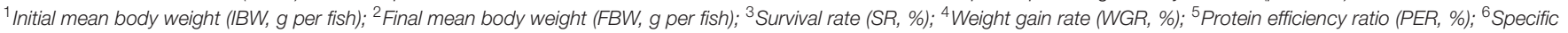
growth rate (SGR, \%/d); ${ }^{7}$ Feed intake (Fl, g/fish); ${ }^{8}$ Feed conversion rate (FCR); ${ }^{9}$ Hepatosomatic index (HSI, \%); and ${ }^{10} \mathrm{Condition}$ factor (CF, g/cm ${ }^{3}$ ).

specific growth rate (SGR), protein efficiency ratio (PER), and condition factor (CF) after starving for $24 \mathrm{~h}$, according to the following formulas:

SR $(\%)=100 \times$ final number (fish)/initial number (fish); Feed intake $(\mathrm{FI}, \mathrm{g} /$ fish $)=$ total feed intake per cage $(\mathrm{g}) /$ (number of fish*82 days); WGR (\%) $=100 \times$ [final weight $(\mathrm{g})$-initial weight $(\mathrm{g})] /$ final weight $(\mathrm{g})$; Feed conversion rate $(\mathrm{FCR})=100$ $\times$ feed supplied $(\mathrm{g}) / \mathrm{WG}(\mathrm{g}) ; \operatorname{SGR}(\% / \mathrm{d})=100 \times[(\ln$ final weight-ln initial weight) $/ 82$ days]; PER $(\%)=100 \% \times[$ final weight $(\mathrm{g})$-initial weight $(\mathrm{g})] /[$ total feed intake $(\mathrm{g}) \times$ content of dietary protein $(\%)]$; CF $\left(\mathrm{g} / \mathrm{cm}^{3}\right)=$ weight $(\mathrm{g}) /$ length ${ }^{3}(\mathrm{~cm})$; Three fishes per cage (nine fishes per diet treatment) were randomly allotted, anesthetized with MS-222 (0.1 g/L) (27), and weighed and measured, and the blood samples were drawn from the caudal vein. And then these fishes were dissected to acquire the hepatopancreas for assessing the hepatosomatic index (HSI), according to the following formulas: HSI $(\%)=100 \times$ [wet weight of hepatopancreas ( $\mathrm{g}$ )/final weight $(\mathrm{g})$ ], and the hepatopancreas was stored at $-20^{\circ} \mathrm{C}$ for chemical analysis and at $-80^{\circ} \mathrm{C}$ for gene expression analysis, respectively. Simultaneously, the dorsal white muscles of these fishes were acquired for the composition analysis, which were stored at $-20^{\circ} \mathrm{C}$. Additionally, three fishes from each cage (nine fishes per diet treatment) were randomly chosen and ground for later proximate composition analysis of the whole body.

\section{Sample Preparation and Biochemical Analysis}

Proximate composition analysis of the diets, whole body, and dorsal white muscle were carried out according to the Association of Official Analytical Chemists (AOAC) (2006) (28) for moisture (drying at $105^{\circ} \mathrm{C}$ for $24 \mathrm{~h}$ ), crude protein (Kjeldahl method; $\mathrm{N} \times$ 6.25), crude ash, and crude lipid (the Soxhlet method).

Serum samples were isolated by high-speed centrifugation at $2,500 \mathrm{rpm}$ at $4^{\circ} \mathrm{C}$ for $20 \mathrm{~min}$. All indices involved in the serum were assayed using specific analytical procedures and commercially available kits, which were supplied by Nanjing
Jiancheng Bioengineering Institute, Nanjing, China. Among these, total cholesterol (TCHO) was determined by $\mathrm{CHOD}$ PAP-CDC method (Cat. No. A111-2-1). Triacylglycerol (TG) was measured by GPD-PAP method (Cat. No. A110-2-1). High-density lipoprotein-cholesterol (HDL-C) and low-density lipoprotein-cholesterol (LDL-C) were measured according to the selective inhibition method (Cat. Nos. A112-1-1 and A113-1-1).

\section{Determination of the Relative Gene Expressions}

Referring to the manufacturer's instructions of RNAiso Plus (TaKaRa, Dalian, Liaoning, China), total RNA extraction of the hepatopancreas samples was carried out. The isolated RNA was spectrophotometrically quantified using a NanoDrop 2000 (Thermo Fisher Scientific, Waltham, MA, USA) and electrophoresed on a $1 \%$ denaturing agarose gel to test the integrity. About 1,000-ng RNA was reverse transcribed into complementary DNA (cDNA) following the manufacturer's instructions of TaKaRa PrimeScript ${ }^{\mathrm{TM}}$ RT reagent Kit with genomic DNA (gDNA) Eraser (Perfect Real Time) (Code No.: RR047A) (Dalian Takara Company, Dalian City, Liaoning Province, China). After the cDNA templates diluted into 50 $\mathrm{ng} / \mu \mathrm{l}$ by DEPC water, the targeted gene expression levels in the cDNA templates were measured by quantitative real-time PCR conducted on ABI 7500 real-time PCR machine (ABI, Applied Biosystems, Waltham, MA, USA) with the TaKaRa SYBR $^{\circledR}$ Premix Ex Taq ${ }^{\mathrm{TM}}$ (Tli RNaseH Plus) (Code No.: RR420A) (Dalian Takara Company, Shiga, Japan). The reaction was conducted in a $20-\mu \mathrm{l}$ volume containing $10 \mu \mathrm{l}$ SYBR $\mathbb{R}$ Premix DimerEraser $(2 \times), 0.4 \mu \mathrm{l}$ PCR Forward Primer, PCR Reverse Primer, $2 \mu \mathrm{l}$ cDNA template $(\approx 100 \mathrm{ng}), 7 \mu$ l RNase free $\mathrm{dH}_{2} \mathrm{O}$ according to the manufacturer's protocol of the TaKaRa

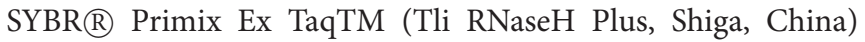
(Code No.: RR420A). The primers were designed based on the obtained sequences from the National Center for Biotechnology Information (NCBI) and listed in Table 2. $\beta$-actin was regarded as a reference gene to normalize cDNA loading. Based on the 
specific gene standard curves, the amplification efficiency of the target and the housekeeping gene was calculated, which was generated from 10 fold serial dilutions. The thermal cycle program of quantitative reverse transcriptase PCR (qRT-PCR) was as follows: $95^{\circ} \mathrm{C}$ for $30 \mathrm{~s}$ (pre-degeneration stage), 40 cycles at $95^{\circ} \mathrm{C}$ for $5 \mathrm{~s}, 60^{\circ} \mathrm{C}$ for $34 \mathrm{~s} \mathrm{(cycling} \mathrm{stage),} \mathrm{then} 95^{\circ} \mathrm{C}$ for $15 \mathrm{~s}, 60^{\circ} \mathrm{C}$ for $1 \mathrm{~min}, 95^{\circ} \mathrm{C}$ for $30 \mathrm{~s}$, and $60^{\circ} \mathrm{C}$ for $15 \mathrm{~s}$ (melt curve stage). The comparative CT method $\left(2^{-\Delta \Delta \mathrm{Ct}}\right)$ method was used to calculate the relative expression levels of each gene.

\section{Statistical Analysis}

The results were presented as the mean $\pm \mathrm{SD}$. All data were subjected to a one-way ANOVA by Duncan's multiple range tests to evaluate significant differences among the treatments at $p<0.05$ using SPSS statistics version 22.0 (SPSS Inc., Chicago, IL, USA). A second-order polynomial regression model was used to estimate the optimal dietary lipid level for large-sized common carp.

\section{RESULTS}

\section{Growth Performance and Feed Utilization}

Survival rates were ranged from 98.67 to $100.00 \%$. Significant enhancements in WGR and SGR were observed by increasing dietary crude lipid levels from 30 to $60 \mathrm{~g} / \mathrm{kg}(p<0.05)$, and further increase of the dietary lipid levels from 90 to $180 \mathrm{~g} / \mathrm{kg}$ resulted in a significant decrease in growth performance $(p<$ $0.05)$. The optimal growth performance of fish with the highest WGR and SGR was found in the $60 \mathrm{~g} / \mathrm{kg}$ dietary lipid treatment, with a significant difference in comparison with other groups $(p$ $<0.05)$. The highest PER, FI, and lowest FCR were observed in the $60 \mathrm{~g} / \mathrm{kg}$ dietary lipid treatment, with a significant difference in comparison with 120,150 , and $180 \mathrm{~g} / \mathrm{kg}$ dietary lipid treatments, respectively $(p<0.05$ ). The highest HSI in the $180 \mathrm{~g} / \mathrm{kg}$ crude lipid group was observed, and the highest CF was observed in the $150 \mathrm{~g} / \mathrm{kg}$ crude lipid group, with significant differences in comparison to the $30 \mathrm{~g} / \mathrm{kg}$ dietary lipid treatment $(p<0.05$; Table 3).

Weight gain rate and FCR were used in the second-order polynomial regression analysis for the estimation of optimum dietary lipid requirement, and the analysis showed that the optimal dietary lipid requirement for maximum growth of largesized common carp was, respectively, estimated to be 59.5 and $70.4 \mathrm{~g} / \mathrm{kg}$ of dry matter (Figures 1, 2).

\section{Whole-Body, Dorsal White Muscle, and Hepatopancreas Compositions}

The highest whole-body crude protein content was obtained in fish fed the $60 \mathrm{~g} / \mathrm{kg}$ dietary lipid treatment. The highest wholebody crude lipid content was observed in fish fed the $180 \mathrm{~g} / \mathrm{kg}$ dietary lipid treatment. The highest muscle crude protein content was obtained in fish fed the $90 \mathrm{~g} / \mathrm{kg}$ dietary lipid treatment, only with no significant difference in comparison to the 60 $\mathrm{g} / \mathrm{kg}$ dietary lipid treatment $(p<0.05)$. The muscle crude lipid content in the $180 \mathrm{~g} / \mathrm{kg}$ dietary lipid treatment was significantly higher than that in other dietary lipid treatments $(p<0.05)$. For the hepatopancreas compositions, the crude lipid content
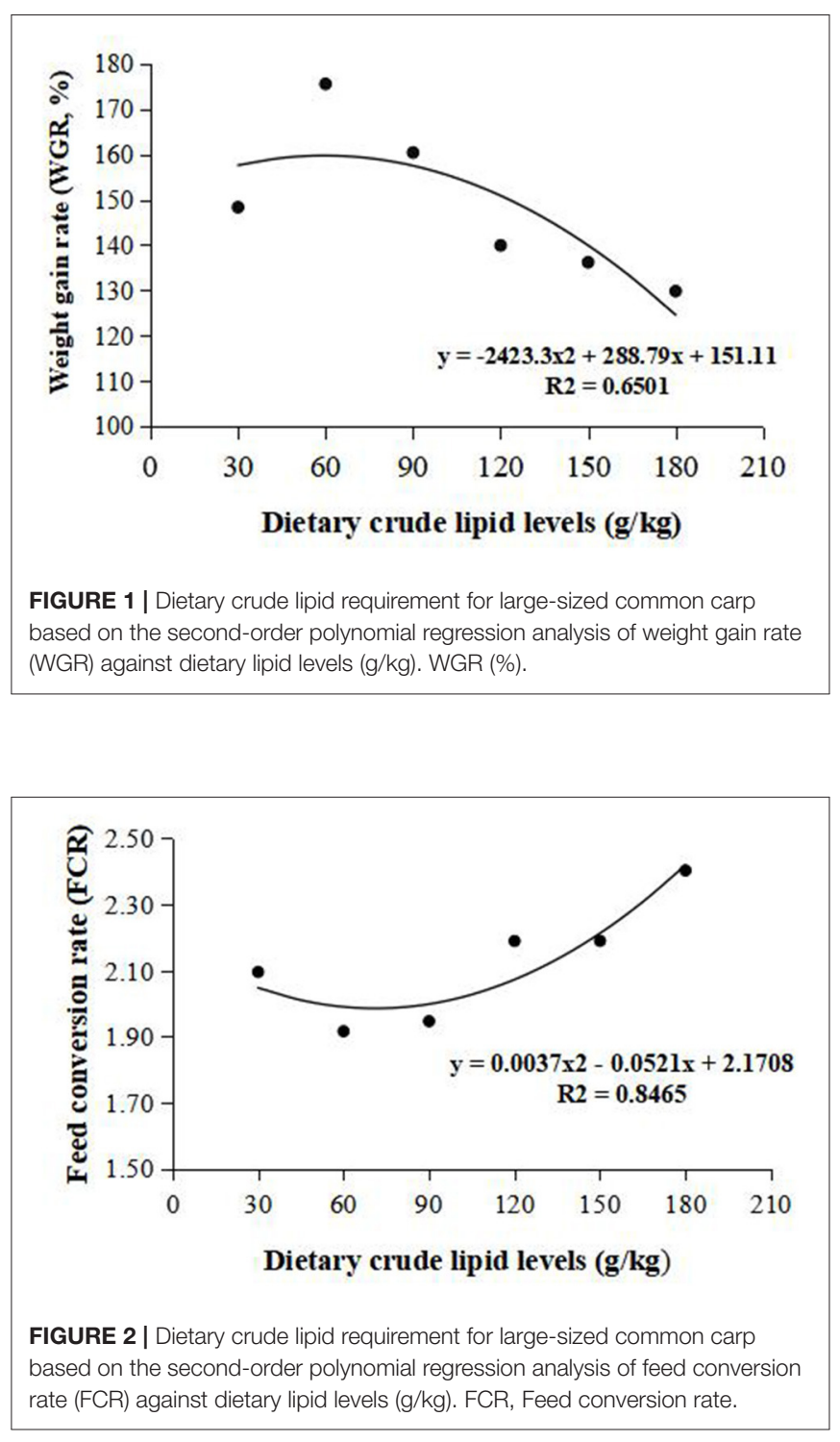

increased with an increase in dietary protein $(p<0.05)$, and the highest crude lipid content of the hepatopancreas was observed in fish fed the $180 \mathrm{~g} / \mathrm{kg}$ dietary lipid treatment, with significant differences from the other dietary lipid treatments $(p<0.05)$. No significant difference was found in the content of moisture of the hepatopancreas in all treatment groups ( $p>0.05$; Table 4).

\section{Serum Biochemical Parameters}

Serum biochemical parameters showed that an obviously higher TCHO content was observed in the $180 \mathrm{~g} / \mathrm{kg}$ dietary lipid treatment than in 30 and $60 \mathrm{~g} / \mathrm{kg}$ dietary lipid treatments $(p<$ $0.05)$. Fish fed the $120 \mathrm{~g} / \mathrm{kg}$ crude lipid diet presented the lowest LDL-C content in serum, with a significant difference in 30 and $60 \mathrm{~g} / \mathrm{kg}$ dietary lipid treatments $(p<0.05$; Table 5). 
TABLE 4 | Whole-body, dorsal white muscle, and hepatopancreas compositions of large-sized common carp fed the diets containing different lipid levels*.

\begin{tabular}{|c|c|c|c|c|c|c|}
\hline \multirow[t]{2}{*}{ Items } & \multicolumn{6}{|c|}{ Varying levels of dietary lipid } \\
\hline & $30 \mathrm{~g} / \mathbf{k g}$ & $60 \mathrm{~g} / \mathrm{kg}$ & $90 \mathrm{~g} / \mathbf{k g}$ & $120 \mathrm{~g} / \mathrm{kg}$ & $150 \mathrm{~g} / \mathrm{kg}$ & $180 \mathrm{~g} / \mathrm{kg}$ \\
\hline \multicolumn{7}{|l|}{ Whole-body } \\
\hline Crude protein/\% & $14.84 \pm 0.21$ & $15.37 \pm 0.33$ & $15.29 \pm 0.74$ & $14.59 \pm 0.18$ & $14.41 \pm 0.15$ & $14.20 \pm 0.54$ \\
\hline Crude lipid/\% & $6.97 \pm 0.49$ & $6.06 \pm 0.34$ & $6.70 \pm 0.15$ & $6.58 \pm 0.35$ & $7.30 \pm 0.64$ & $7.73 \pm 0.25$ \\
\hline Moisture/\% & $72.37 \pm 1.13$ & $73.81 \pm 1.88$ & $73.34 \pm 0.41$ & $74.53 \pm 1.74$ & $74.35 \pm 1.84$ & $73.13 \pm 1.25$ \\
\hline Ash/\% & $2.87 \pm 0.06$ & $3.04 \pm 0.02$ & $2.93 \pm 0.13$ & $2.76 \pm 0.21$ & $2.86 \pm 0.06$ & $2.94 \pm 0.03$ \\
\hline \multicolumn{7}{|c|}{ Dorsal white muscle } \\
\hline Crude protein/\% & $10.01 \pm 0.12^{d}$ & $13.01 \pm 0.45^{a}$ & $13.36 \pm 0.31^{a}$ & $12.49 \pm 0.09^{a b}$ & $12.28 \pm 0.34^{b}$ & $11.28 \pm 0.51^{c}$ \\
\hline Crude lipid/\% & $2.33 \pm 0.06^{\mathrm{cd}}$ & $2.18 \pm 0.06^{d}$ & $2.19 \pm 0.02^{d}$ & $2.38 \pm 0.05^{c}$ & $2.71 \pm 0.53^{b}$ & $3.07 \pm 0.06^{a}$ \\
\hline Moisture/\% & $77.37 \pm 0.19$ & $78.17 \pm 0.40$ & $78.59 \pm 0.56$ & $78.21 \pm 0.24$ & $77.46 \pm 0.33$ & $77.46 \pm 0.33$ \\
\hline Ash/\% & $1.24 \pm 0.06$ & $1.13 \pm 0.04$ & $1.16 \pm 0.06$ & $1.13 \pm 0.03$ & $1.14 \pm 0.02$ & $1.15 \pm 0.06$ \\
\hline \multicolumn{7}{|l|}{ Hepatopancreas } \\
\hline Crude lipid/\% & $6.97 \pm 0.32^{d}$ & $7.12 \pm 0.19^{d}$ & $7.13 \pm 0.16^{d}$ & $7.82 \pm 0.04^{c}$ & $9.30 \pm 0.19^{b}$ & $11.06 \pm 0.19^{a}$ \\
\hline Moisture/\% & $72.45 \pm 0.82$ & $72.16 \pm 0.44$ & $74.65 \pm 0.39$ & $73.44 \pm 0.65$ & $70.69 \pm 0.34$ & $73.88 \pm 0.25$ \\
\hline
\end{tabular}

*Values are the mean $\pm S D(n=3)$ of three replicates.

Values within the same row with different small letters in superscript are significantly different $(p<0.05)$.

TABLE 5 | Serum biochemical parameters of large-sized common carp fed the diets containing different lipid levels ${ }^{\star}$.

\begin{tabular}{|c|c|c|c|c|c|c|}
\hline \multirow[t]{2}{*}{ Items } & \multicolumn{6}{|c|}{ Varying levels of dietary lipid } \\
\hline & $30 \mathrm{~g} / \mathbf{k g}$ & $60 \mathrm{~g} / \mathrm{kg}$ & $90 \mathrm{~g} / \mathbf{k g}$ & $120 \mathrm{~g} / \mathrm{kg}$ & $150 \mathrm{~g} / \mathrm{kg}$ & $180 \mathrm{~g} / \mathrm{kg}$ \\
\hline $\mathrm{TG} /(\mathrm{mM})^{1}$ & $0.96 \pm 0.03$ & $0.92 \pm 0.06$ & $0.81 \pm 0.07$ & $0.91 \pm 0.07$ & $0.96 \pm 0.06$ & $0.92 \pm 0.09$ \\
\hline $\mathrm{TCHO} /(\mathrm{mM})^{2}$ & $3.14 \pm 0.21^{b}$ & $3.17 \pm 0.15^{b}$ & $3.49 \pm 0.09^{a b}$ & $3.37 \pm 0.2^{a b}$ & $3.62 \pm 0.25^{a b}$ & $3.85 \pm 0.23^{a}$ \\
\hline $\mathrm{HDL}-\mathrm{C} /(\mathrm{mM})^{3}$ & $1.64 \pm 0.07$ & $1.63 \pm 0.06$ & $1.74 \pm 0.04$ & $1.77 \pm 0.07$ & $1.67 \pm 0.09$ & $1.84 \pm 0.09$ \\
\hline LDL-C/(mM) ${ }^{4}$ & $0.80 \pm 0.08^{b}$ & $0.85 \pm 0.08^{b}$ & $0.97 \pm 0.04^{\mathrm{ab}}$ & $1.06 \pm 0.11^{\mathrm{ab}}$ & $1.12 \pm 0.11^{\mathrm{a}}$ & $0.94 \pm 0.08^{a b}$ \\
\hline
\end{tabular}

*Values are the mean $\pm S D(n=3)$ of three replicates.

Values within the same row with different small letters in superscript are significantly different $(p<0.05)$.

${ }^{1}$ Triacylglycerol (TG); ${ }^{2}$ Total cholesterol (TCHO); ${ }^{3}$ High-density lipoprotein-cholesterol (HDL-C); and ${ }^{4}$ Low-density lipoprotein-cholesterol (LDL-C).

\section{Relative Gene Expressions of the Growth Hormone/Insulin-Like Growth Factor-1 Axis}

Significant improvements in the relative gene expressions of growth hormone $(\mathrm{GH})$ and insulin-like growth factor-1 (IGF-1) were found with an increase in the dietary lipid levels from 30 to $60 \mathrm{~g} / \mathrm{kg}(p<0.05)$, and further increases in the dietary lipid levels from 90 to $180 \mathrm{~g} / \mathrm{kg}$ resulted in a significant decrease of relative gene expressions $(p<0.05)$. The peak values of relative gene expression of GH and IGF-1 were observed in the $60 \mathrm{~g} / \mathrm{kg}$ dietary lipid treatment, with a significant difference in the other dietary lipid treatments $(p<0.05)$. The lowest GH and IGF-1 relative gene expression were both found in the $30 \mathrm{~g} / \mathrm{kg}$ dietary lipid treatment, but no significant difference was observed compared to the $180 \mathrm{~g} / \mathrm{kg}$ dietary lipid treatment ( $p>0.05$; Figure 3 ).

\section{Relative Gene Expressions of Lipid Metabolism}

For the relative gene expression for lipid synthesis in the hepatopancreas, significant improvements in the relative gene expression of fatty acid synthase (FAS), acetyl-CoA carboxylase-1 (ACC-1), and sterol regulatory element binding protein (SREBP) were observed with an increase in dietary crude lipids from 30 to $90 \mathrm{~g} / \mathrm{kg}(p<0.05)$, and a significant decrease in relative gene expression of FAS, ACC-1, and SREBP resulted in further increment of crude lipids to 120 and $180 \mathrm{~g} / \mathrm{kg}(p<0.05)$. Moreover, the peak values of the relative gene expression of FAS and ACC-1 were observed in the $90 \mathrm{~g} / \mathrm{kg}$ dietary lipid treatment $(p<0.05)$. The peak value of relative gene expression of SREBP was observed in the $60 \mathrm{~g} / \mathrm{kg}$ dietary lipid treatment, and it did not significantly differ from the $120 \mathrm{~g} / \mathrm{kg}$ dietary lipid treatment $(p<$ 0.05; Figure 4).

For the relative gene expressions associated with lipid catabolism in the hepatopancreas, lipoprotein lipase (LPL), and carnitine palmitoyltransferase-1 (CPT1), relative gene expression levels in the hepatopancreas were both upregulated with an increase in the dietary lipid levels in the $180 \mathrm{~g} / \mathrm{kg}$ dietary lipid treatment, and the peak values of the relative gene expression of LPL and CPT1 were observed in the $180 \mathrm{~g} / \mathrm{kg}$ dietary lipid treatment, with a significant difference in the other dietary lipid treatments ( $p<0.05$; Figure 5). 


\section{DISCUSSION}

A typical dose-response effect of dietary crude lipids on growth performance of large-sized common carp with an IBW of $247.00 \pm 16.67 \mathrm{~g}$ was observed, with the highest WGR and SGR corresponding to fish fed the $60 \mathrm{~g} / \mathrm{kg}$ lipid diets while a reduction in growth performance was found as the dietary crude lipid increased beyond this level. Analogously, a typical carnivorous marine fish Argyrosomus regius with an IBW of $229.7 \pm 1.4 \mathrm{~g}$ fed a $170 \mathrm{~g} / \mathrm{kg}$ lipid diet acquired the superior growth performance compared with fish fed 130 and $210 \mathrm{~g} / \mathrm{kg}$ diets, and increasing the dietary lipid levels from 170 to $210 \mathrm{~g} / \mathrm{kg}$ led to impaired growth performance (29). A typical herbivorous freshwater fish (Ctenopharyngodon idella) with an IBW of $261.41 \pm 0.53 \mathrm{~g}$ showed a significantly higher SGR in fish fed a $36 \mathrm{~g} / \mathrm{kg}$ lipid diet

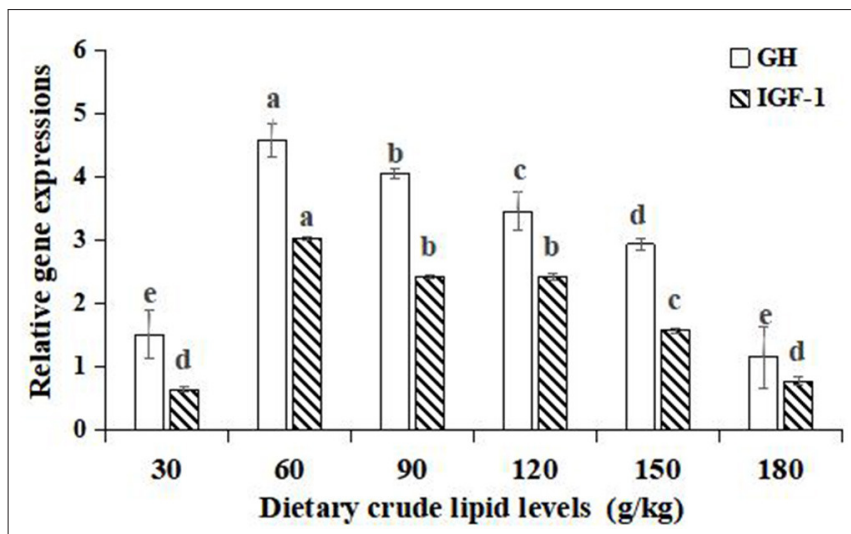

FIGURE 3 | Relative gene expressions of the GH/IGF-1 axis in the hepatopancreas of large-sized common carp fed the diets containing different lipid levels. Lowercase letters ( $a, b, c$, or d) indicate a significant effect of relative gene expressions of the $\mathrm{GH} / \mathrm{IGF}-1$ axis in the hepatopancreas $(p<0.05)$. GH, Growth hormone; IGF-1, Insulin growth factor-1. in comparison to those fed diets containing lipid levels of 5.9, $21.4,66.6$, or $80.1 \mathrm{~g} / \mathrm{kg}$ (30). Based upon a series of discoveries, for the large-sized fish, we draw a conclusion that excessively low or high dietary lipid levels resulted in growth inhibition as a result of deficient or imbalanced nutrients. However, it is worth pointing out that the three fish species in the abovementioned studies belong to warm-water sciaenids. In sharp contrast to what has been described for warm-water sciaenids, there was an obvious linear relationship between the dietary lipid levels and growth performance in some cold-water species, such as large-sized triploid rainbow trout (Oncorhynchus mykiss) with an IBW of $233 \mathrm{~g}$, which was reported to present a better growth performance when fed a $290 \mathrm{~g} / \mathrm{kg}$ lipid diet rather than other lower dietary lipid levels (31), or Atlantic salmon (Salmo salar) with $1,026 \mathrm{~g}$, which had higher growth rates when fed a 380$470 \mathrm{~g} / \mathrm{kg}$ lipid diet, than when fed a $310 \mathrm{~g} / \mathrm{kg}$ lipid diet (32). Consequently, when confirming the dietary lipid requirement, we should need to consider the biological characteristics of different fish species. From the standpoint of feed utilization, a deterioration in FCR was observed in fish fed high-lipid diets, which corresponded to the reduction of WGR and SGR. As it turned out, the FCR reached the maximum value $(2.40 \pm 0.03)$ in fish fed a $180 \mathrm{~g} / \mathrm{kg}$ crude lipid diet, and was significantly higher compared to that of the fish in the other treatments. Simultaneously, a significant decline in PER was observed in fish fed a $180 \mathrm{~g} / \mathrm{kg}$ crude lipid diet compared to fish in the other treatments. The above findings implied that the escalating dietary lipid levels exerted a passive influence on the nutrient utilization for fish, exactly as has been reported as the findings in the study on tench (Tinca tinca L.) with an IBW of $0.382 \pm$ $0.08 \mathrm{~g}$ (33), common sole (Solea solea) with an IBW of $13.8 \pm$ $0.4 \mathrm{~g}$ (12), common carp with an IBW of $36.12 \pm 1.18 \mathrm{~g}$ (5), A. regius with an IBW of $229.7 \pm 1.4 \mathrm{~g}$ (29). This discovery might also imply that a significant protein-sparing effect could not be effectually realized in many fish species by excessive dietary lipid supplements.

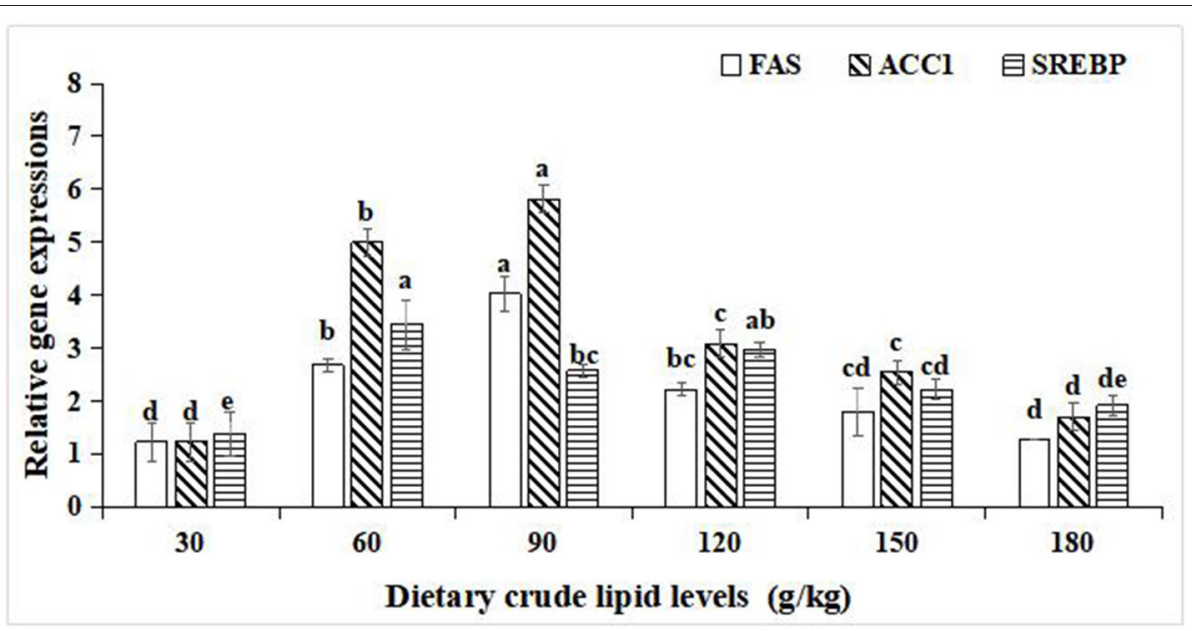

FIGURE 4 | Relative gene expressions of lipid metabolism in the hepatopancreas of large-sized common carp fed the diets containing different lipid levels. Lowercase letters ( $a, b, c$, or d) indicate a significant effect of relative gene expressions of lipid synthesis in the hepatopancreas ( $p<0.05)$. FAS, Fatty acid synthase; SREBP, Sterol regulatory element binding protein; ACC-1, Acetyl-CoA carboxylase-1. 


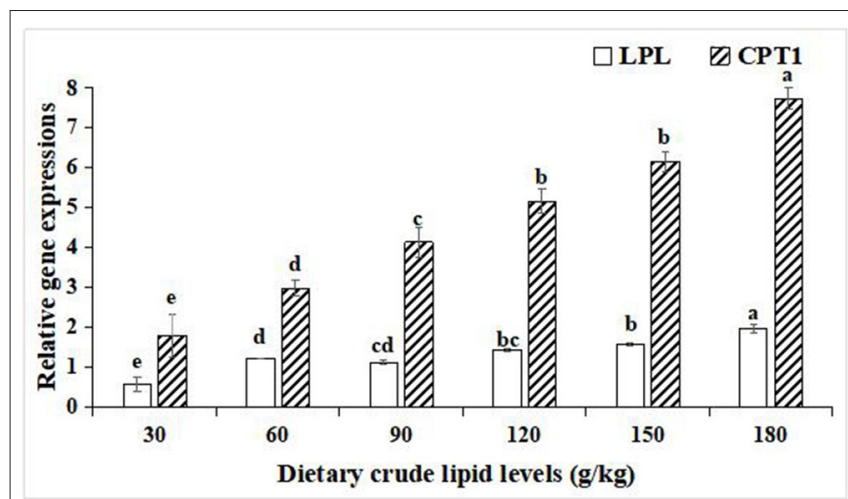

FIGURE 5 | Relative gene expressions of lipid metabolism in the hepatopancreas of large-sized common carp fed the diets containing different lipid levels. Lowercase letters ( $a, b, c$, or $d$ ) indicate a significant effect of relative gene expressions of lipid catabolism in the hepatopancreas $(p<0.05)$. LPL, Lipoprotein lipase; CPT1, Carnitine palmitoyltransferase-1.

Based on the strength of the second-order polynomial regression analysis of WGR and FCR, the requirement of dietary lipids for large-sized common carp with an IBW of $247.00 \pm$ $16.67 \mathrm{~g}$ was estimated to be $59.5-70.4 \mathrm{~g} / \mathrm{kg}$. This requirement is $10-30 \mathrm{~g} / \mathrm{kg}$ lower than that observed in common carp with an IBW of $5.51 \pm 0.05 \mathrm{~g}$ (24), common carp with an IBW of $15 \mathrm{~g}$ (26), and common carp with an IBW of $36.12 \pm 1.18 \mathrm{~g}$ (5). The above difference supports somehow the hypothesis that there is a more excellent nutritional requirement in the juvenile stage. For one thing, small-sized fish is in a rapid growth period, so fish can use more dietary proteins for protein deposition to reduce the proportion of protein used for energy consumption. Hence, the diets of juvenile fish need more non-protein energy sources to meet the energy for body metabolism. However, large-sized fish is in a slow growth period, so appropriate diet lipid contents can promote the growth, whereas excessive dietary lipids will cause the liver steatosis and lipid oxidative stress, thereby deteriorating growth and health status of fish $(27,34)$. There exists, in addition, an obvious difference in lipid synthesis capacity between smallsized fish and large-sized fish. Phospholipid is a kind of lipid and an important component of lipoprotein. The lack of lipoprotein can lead to fat deposition in the liver. Therefore, the addition of $30-60 \mathrm{~g} / \mathrm{kg}$ phospholipids in diets is necessary for the small-size fish. For large-sized fish, the ability to synthesize phospholipids will be strengthened, which implies that a large-sized fish has the stronger ability to synthesize lipid in comparison to a small-sized fish (35). The change trend of lipid metabolic regulation with fish weight needs to be lucubrated in future.

Apart from external manifestations, such as FCR, PER, and so on, internal manifestations, such as the protein relative gene expression of the GH/IGF axis in the muscle or liver and deposition in the whole body or muscle, play an irreplaceable role in hastening growth $(36,37)$. As expected in our study, in accordance with the change trend of growth performance, the hepatic GH and IGF-1 expression levels reached peaks with the dietary lipid levels up to $60 \mathrm{~g} / \mathrm{kg}$ and did not increase further with higher lipid levels. A few studies on pejerrey (Odontesthes bonariensis) (38) and rainbow trout (31) have also revealed that the optimal dietary lipid level improved the growth of fish by promoting the proper functioning of the GH/IGF axis. Furthermore, the whole-body and muscle protein contents obtained the maximum levels with the dietary lipid levels up to 60 and $90 \mathrm{~g} / \mathrm{kg}$, respectively, and did not also increase further with higher lipid levels, indicating that dietary lipids would be important for the protein-sparing effect when ranging from 60 to $90 \mathrm{~g} / \mathrm{kg}$. These results nearly fell within the estimated optimal lipid level range of large-sized common carp $(59.5-70.4 \mathrm{~g} / \mathrm{kg}$ ) based on the second-order polynomial regression analysis of WGR and FCR.

As already pointed out by Shearer (39), the lipid content of the whole body and tissues would be susceptible to some exogenous factors, especially diets. In the current study, the whole-body lipid content of the fish fed a $180 \mathrm{~g} / \mathrm{kg}$ crude lipid diet reached the highest value although it was not significantly different from the other treatments. Furthermore, fish fed the $120-180 \mathrm{~g} / \mathrm{kg}$ crude lipid diets obtained significantly higher muscle and hepatopancreas lipid contents than fish fed lower crude lipid treatments, and fish fed a $180 \mathrm{~g} / \mathrm{kg}$ crude lipid diet obtained the highest muscle lipid content $(30.7 \pm 0.6$ $\mathrm{g} / \mathrm{kg}$ ) and hepatopancreas lipid content (110.6 $\pm 1.9 \mathrm{~g} / \mathrm{kg})$. These findings obtained were similar to those obtained in other fish species, such as channel catfish (40), red drum (Sciaenop socellata) (41), rainbow trout (42), grass carp (43), and sea cucumber (Apostichopus japonicus) (44), verifying that undue dietary lipid supplements would cause excessive lipid deposition in the visceral cavity and tissues.

Because the crude lipid content in the muscle of large-sized common carp ranged from 23.3 to $30.7 \mathrm{~g} / \mathrm{kg}$, in fish fed the 30 and $180 \mathrm{~g} / \mathrm{kg}$ crude lipid diets, respectively, this species would be categorized as low-fat fish, according to the classification of fishes depending on their meat lipid content (45). This result provided a solid evidence for the fact that common carp has a restricted capacity for lipid deposition in the muscle, which was consistent with other species such as meager with an IBW of $229.7 \pm 1.4 \mathrm{~g}$ (29). In contrast to meager with an IBW of $229.7 \pm 1.4 \mathrm{~g}$ (29), the hepatopancreas was significantly affected by the dietary lipid levels since there were not only merely significant differences in the HSIs but also in the lipid content of hepatopancreas among the six treatments. The obtained result was similar to that obtained in a study on gilt-head sea bream (Chrysophyrys auratus), European seabass (Dicentrarchus labrax) (46), and Chelon haematocheilus (47), implying that the hepatopancreas (or say liver) was most likely to be a major lipid deposition site in common carp. Nevertheless, it should be pointed out that further research on the lipid deposition pattern among different fish species, fish sizes, and growth stages also needs to be strengthened.

Blood is the carrier of nutrients and metabolic waste in a live animal, and blood lipid can reflect the status of lipid metabolism in vivo. If a hepatocyte structure or the function of the liver is impaired, The concentrations of TG and TCHO in plasma will rise sharply (48). In the current study, despite no significant difference in TG contents among all treatments, significant 
improvements in the TCHO content of serum were observed with an increase in the dietary lipid levels, suggesting that an endogenous lipid transport remained in a state of animation. Different from our findings, research on C. haematocheilus reported a lack of significant differences in the concentrations of TG and TCHO in plasma (47). This discrepancy might be ascribed to a difference in the trend change of HDL-C contents. HDL-C is considered as a crucial tool for transporting the cholesterol from tissue cells back to liver for metabolic transformation (48). Research on C. haematocheilus found that HDL-C contents were significantly increased by an increase in the dietary lipid levels (47) while our research found that there was no significant difference among the six experimental groups in the HDL-C contents of serum. Hence, the shortage in HDL$\mathrm{C}$, which played a negative role in promptly removing excess cholesterol from blood and tissue cells, might be a major element in affecting the metabolic balance of blood lipid and liver lipid. As a method of alleviating the metabolic burden of liver lipid, the LDL-C in the blood should not be ignored because it is the primary vehicle for transporting cholesterol to extrahepatic tissues (48). In agreement to this, a significant increment in the LDL-C content of serum was registered in large-sized common carp with an increase in the dietary lipid levels. Combined with the result of molecular biology, these results seem to imply that the body is actively coping with the metabolic burden generated by high-lipid diets although the goal of reducing lipid deposition in the hepatopancreas has not been achieved. Hence, further research on improving lipid metabolism of the hepatopancreas in fish needs to be conducted.

In the hepatopancreas, the expression levels of lipogenic genes and lipolysis genes reflect the lipometabolic state for fish (49). In the present study, with an increase of the dietary lipid level from 30 to $90 \mathrm{~g} / \mathrm{kg}$, the expression levels of lipogenic genes FAS, ACC1 , and SREBP1 gradually increased, while with an increase in the dietary lipid levels from 120 to $180 \mathrm{~g} / \mathrm{kg}$, the expression levels of FAS, ACC-1, and SREBP1 significantly decreased. In addition, the expression levels of lipolysis genes LPL and CPT1 were lifted as the dietary lipid levels increased, but the expression levels of LPL and CPT1 in 30, 60, and $90 \mathrm{~g} / \mathrm{kg}$ dietary lipid treatments were significantly lower than those of other three treatments. It was suggested that there were different metabolic adaptation mechanisms between high- and low-lipid diets for large-sized common carp. When fed the low-lipid diets, large-sized common carp would enhance the endogenous lipid synthesis of the hepatopancreas and relatively weaken the endogenous lipodysis to address an insufficient intake of exogenous lipid, and this was consistent with the results studied on grass carp fed low-lipid diets (50). In contrast, if faced with an excess of dietary lipid supplement, upregulation in the expression levels of FAS, ACC1 , and SREBP1 and relative downregulation in the expression levels of LPL and CPT1 in the hepatopancreas of large-sized common carp were conducted to maintain the dynamic and metabolic balance between the absorption and utilization of exogenous dietary lipids and endogenous lipid synthesis (51). Similar findings were reported in rainbow trout (52), GIFT tilapia (Oreochromis niloticus) (53), and Onychostoma macrolepis (54). In addition, it needs to be emphasized that the lowest expressions of lipogenic genes and lipolysis genes in the hepatopancreas were observed in the $30 \mathrm{~g} / \mathrm{kg}$ treatment, indicating that a restrictive and an insufficient lipid intake induced to nutritional dysregulation stress for large-sized common carp (55).

\section{CONCLUSION}

Excessive amount of dietary crude lipid generates a lipid metabolic burden for large-sized common carp and results in worsening of growth performance and feed utilization efficiency, the higher TCHO contents in serum, the higher muscle and hepatopancreas lipid deposition, and a less-than-ideal proteinsparing effect. The results revealed that an excessive amount of dietary lipid supplements (>60 mg/kg) would inhibit WG and aggravate the lipid decomposition in the hepatopancreas. Based on WGR and FCR, the dietary lipid levels of 59.5 and $70.4 \mathrm{~g} / \mathrm{kg}$ were optimal for growth performance and feed utilization of large-sized common carp. This should be taken into consideration in formulating specific practical diets for largesized common carp.

\section{DATA AVAILABILITY STATEMENT}

The original contributions presented in the study are included in the article/supplementary material, further inquiries can be directed to the corresponding author/s.

\section{ETHICS STATEMENT}

The animal study was reviewed and approved by the Committee for the Welfare and Ethics of Laboratory Animals of Heilongjiang River Fisheries Research Institute, CAFS.

\section{AUTHOR CONTRIBUTIONS}

LW: Conceptualization, investigation, writing-review and editing. ZF: Writing the original draft preparation, formal analysis and resources. DW: Formal analysis and investigation. JL, YZ, and CW: Formal analysis. XZ: Project administration and investigation. All authors contributed to the article and approved the submitted version.

\section{FUNDING}

This research was supported by Central Public-interest Scientific Institution Basal Research Fund, HRFRI (No. HSY202111Q), Natural Science Foundation of China, NSFC (No. 32072972), China, Agriculture Research System of MOF and MARA, and the Central Public-interest Scientific Institution Basal Research Fund, CAFS, China (2018HYZD0503).

\section{ACKNOWLEDGMENTS}

The authors also thank International Science Editing (http://www.internationalscienceediting.com) for editing this manuscript. 


\section{REFERENCES}

1. Ai CX, Tao QY. The replacement of fish meal-the technical strategy of development of aquatic compound feed in the case of the high price of fish meal. Feed Industry. (2013) 34:1-7. https://doi.org/CNKI:SUN:FEED.0.201310-002

2. Fan Z, Cheng ZY, Zhang BL, Zhai SL, Sun JH, Bai DQ, et al. Progress of carbohydrate utilization in common carp (Cyprinus carpio). China feed. (2017) $17: 31-36+44$.

3. Fan Z, Wu D, Li JN, Zhang YY, Xu QY, Wang L S. Dietary protein requirement for on-growing Songpu mirror carp (Cyprinus carpio Songpu). Aquac Nutr. (2020) 26:1748-59. doi: 10.1111/anu.13125

4. Gao W, Liu YJ, Tian LX, Mai KS, Liang GY, Yang HJ, et al. Proteinsparing capability of dietary lipid in herbivorous and omnivorous freshwater finfish: a comparative case study on grass carp (Ctenopharyngodon idella) and tilapia (Oreochromis niloticus $\times$ O. aureus). Aquac Nutr. (2011) 17:211. doi: 10.1111/j.1365-2095.2009.00698.x

5. Fan Z, Li JH, Cheng ZY, Zhang BL, Qu M, Sun JH, et al. Protein sparing effect of lipid diets for common carp (Cyprinus carpio). Adv Eng Softw. (2015) 45:357-68. doi: 10.2991/isesce-15.2015.73

6. Welengane E, Yuji SR, de José Á, Bicudo A. Protein-sparing effect by dietary lipid increase in juveniles of the hybrid fish tambatinga ( $q$ Colossoma macropomum $\times$ ơ $^{T}$ Piaractus brachypomus). Aquac Nutr. (2019) 25:127280. doi: 10.1111/anu.12941

7. Ning LJ Li JM, Sun SX, Du ZY. Fatty acid $\beta$-oxidation in fish: a review. $J$ Fisheries of China. (2019) 43:128-42.

8. Yang B, Ma YX, Shen SB. Rethinking of using lipids in feed industry. Chinese J Anim Nutr. (2019) 31:4901-8. doi: 10.1016/j.clnu.2017.07.004

9. Izquierdo M, Socorro J, Arantzamendi L, Hernández-Cruz C. Recent advances in lipid nutrition in fish larvae. Fish Physiol Biochem. (2000) 22:97107. doi: 10.1023/A:1007810506259

10. Tocher DR, Bendiksen E, Campbell PJ, Bell JG. The role of phospholipids in nutrition and metabolism of teleost fish. Aquac. (2008) 280:2134. doi: 10.1016/j.aquaculture.2008.04.034

11. National Research Council (NRC). Nutrient Requirements of Fish and Shrimp. Washington, DC: National Academy Press (2011).

12. Bonvini E, Parma L, Mandrioli L, Sirri R, Brachelente C, Mongile F, et al. Feeding common sole (Solea solea) juveniles with increasing dietary lipid levels affects growth, feed utilization and gut health. Aquac. (2015) 449:8793. doi: 10.1016/j.aquaculture.2015.01.013

13. Trenzado CE, Carmona R, Merino R, García-Gallego M, Furné M, Domezain A. Effect of dietary lipid content and stocking density on digestive enzymes profile and intestinal histology of rainbow trout (Oncorhynchus mykiss). Aquac. (2018) 497:10-6. doi: 10.1016/j.aquaculture.2018.07.031

14. Ling S, Hashim R, Kolkovski S, Chong ASC. Effects of varying dietary lipid and protein levels on growth and reproductive performance of female swordtail (Xiphorus helleri, Poeciliidae). Aquac Res. (2006) 37:126775. doi: 10.1111/j.1365-2109.2006.01554.x

15. Gaylord TG, Gatlin DM. Dietary lipid level but not L-carnitine affects growth performance of hybrid striped bass (Morone chrysops $\times$ M. saxatilis). Aquac. (2000) 190:237-46. doi: 10.1016/S0044-8486(00)00404-X

16. Wang JT, Liu YJ, Tian LX, Mai KS, Du ZY, Wang Y, et al. Effect of dietary lipid level on growth performance, lipid deposition, hepatic lipogenesis in juvenile cobia (Rachycentron canadum). Aquac. (2005) 249:439-47. doi: 10.1016/j.aquaculture.2005.04.038

17. Kjær MA, Vegusdal A, Gjoen T, Rustan AC, Todorcevic M, Ruyter B. Effect of rapeseed oil and dietary n-3 fatty acids on triacylglycerol synthesis and secretion in Atlantic salmon hepatocytes. Biochim Biophys Acta. (2008) 1781:112-22. doi: 10.1016/j.bbalip.2007.12.004

18. Miller CL, Davis DA, Phelpsk RP. The effects of dietary protein and lipid on growth and body composition of juvenile and on-growing red snapper Lutjanus compechanus (Poey 1860). Aquac Res. (2005) 36:5260. doi: 10.1111/j.1365-2109.2004.01183.x

19. Kloskowsk J. Impact of common carp Cyprinus carpio on aquatic communities: direct trophic e?ects versus habitat deterioration. Fundam Appl Limnol. (2011) 178:245-55. doi: 10.1127/1863-9135/2011/01780245
20. Rahman MM. Role of common carp (Cyprinus carpio) in aquaculture production systems. Front Life Sci. (2015) 8:399410. doi: 10.1080/21553769.2015.1045629

21. Naylor RL, Goldburg RJ, Primavera JH, Kautsky N, Beveridge MC, Clay J, et al. Effect of aquaculture on world fish supplies. Nature. (2000) 405:1017. doi: $10.1038 / 35016500$

22. Food and Agriculture Organization of the United Nations (FAO). Global Aquaculture Production. (2019). Available online at: http://www.fao.org/ fishery/statistics/global-aquaculture-production/en.

23. Fishery administration, Ministry of Agriculture and Rural Affairs, National aquatic technology extension station, China Society of Fisheries. China Fishery Statistical Yearbook. Beijing: China Agriculture Press. (2019).

24. Xu ZC, Liu $\mathrm{H}, \mathrm{Xu}$ QY, Wang CA, Xu H. Effects of dietary lipid levels on immunity and antioxidant function in Songpu mirror carp at different temperatures. J Dalian Ocean Uni. (2012) 27:429-35. doi: 10.3389/fimmu.2021.690234

25. Poleksić V, Stanković M, Marković Z, Relić R, Lakić N, Dulić Z, et al. Morphological and physiological evaluation of common carp (Cyprinus carpio L., 1758) fed extruded compound feeds containing different fat levels. Aquac Int. (2014) 22:289-98. doi: 10.1007/s10499-013-9654-5

26. Zhu XM Li SJ, Jiang XD. Applied values of energetics on developing and evaluating of aquatic formulated diets. J Oceanogra Taiwan. (2001) 20:29-35. https://dx.doi.org/10.1093\%2Filar.53.2.14410.1093/ilar.53.2.144

27. Lv SW, Lei HT, Sun YM. Research progress in safety of fish anesthetics. Food Science. (2012) 33:267-70.

28. Association of Official Analytical Chemists (AOAC). Official Methods of Analysis of the Association of Official Analytical Chemists, 18th edn. Washington, DC: AOAC. (2005).

29. Chatzifotis S, Panagiotidou M, Papaioannou N, Pavlidis M, Nengas I, Mylonas CC. Effect of dietary lipid levels on growth, feed utilization, body composition and serum metabolites of meagre (Argyrosomus regius) juveniles. Aquace. (2010) 307:65-70. doi: 10.1016/j.aquaculture.2010.07.002

30. Ni PJ, Jiang WD, Wu P, Liu Y, Kuang SY, Tang L, et al. Dietary low or excess levels of lipids reduced growth performance, and impaired immune function and structure of head kidney, spleen and skin in young grass carp (Ctenopharyngodon idella) under the infection of Aeromonas hydrophila. Fish Shellfish Immunol. (2016) 55:28-47. doi: 10.1016/j.fsi.2016.03.163

31. Meng YQ, Qian KK, Ma R, Liu XH, Han BY, Wu JH, et al. Effects of dietary lipid levels on sub-adult triploid rainbow trout (Oncorhynchus mykiss): 1. Growth performance, digestive ability, health status and expression of growth-related genes. Aquac. (2019) 513:734394. doi: 10.1016/j.aquaculture.2019.734394

32. Hemre GI, Sandnes K. Effect of dietary lipid level on muscle composition of Atlantic salmon Salmo salar. Aquac Nutr. (1999) 5:9-16. doi: 10.1046/j.1365-2095.1999.00081.x

33. Sáez-Royuela M, Casado M, Celada JD, Carral JM. González-Rodríguez A. Effect of dietary lipid level on survival, growth performance and body composition of juvenile tench (Tinca tinca L) fed practical diets. Aquaculture. (2015) 439:14-9. doi: 10.1016/j.aquaculture.2015.01.017

34. Watanabe K, Hara Y, Ura K, Yada T, Kiron V, Satoh S, et al. Energy and protein requirements for maximum growth and maintenance of body weight of yellow tail. Fisheries Sci. (2000) 66:884-93. doi: 10.1046/j.1444-2906.2000.00143.x

35. Cheng HL, Xia DQ, Wu TT. Fatty liver and regulation of lipids metabolism in fish. Chinese J Ani Nutr. (2006) 18:294-8.

36. Webb KA, Gatlin III DM. Effects of dietary protein level and form on production characteristics and ammonia excretion of red drum Sciaenops ocellatus. Aquac. (2003) 225:17-26. doi: 10.1016/S0044-8486(03)00274-6

37. Rolland M, Dalsgaard J, Holm J, Gómez-Requeni P. Skov, P.V. Dietary methionine level affects growth performance and hepatic gene expression of GH-IGF system and protein turnover regulators in rainbow trout (Oncorhynchus mykiss) fed plant protein-based diets comparative biochemistry and physiology part B: biochemistry and molecular biology. (2015) 181:33-41. doi: 10.1016/j.cbpb.2014.11.009

38. Gómez-Requeni P, Kraemer MN, Canosa LF. Regulation of somatic growth and gene expression of the GH-IGF system and PRP-PACAP by dietary lipid level in early juveniles of a teleost fish, the pejerrey (Odontesthes bonariensis). J Comparat Physiol B. (2012) 182:517-30. doi: 10.1007/s00360-011-0640-9 
39. Shearer KD. Factors affecting the proximate composition of cultured fishes with emphasis on salmonids. Aquac. (1994) 119:63-88. doi: 10.1016/0044-8486(94)90444-8

40. Garling DL, Wilson RP. Optimum dietary protein to energy ratio for channel catfish fingerlings, Ictalurus punctatus. J Nutr. (1976) 16:136875. doi: $10.1093 / \mathrm{jn} / 106.9 .1368$

41. Daniels WH, Robinson EH. Protein and energy requirements of juvenile red drum (Sciaenops ocellatus). Aquac. (1986) 53:243-52. doi: 10.1016/0044-8486(86)90354-6

42. Jobling M, Koskela J, Savolainen R. In?uence of dietary fat level and increased adiposity on growth and fat deposition in rainbow trout, Oncorhynchus mykiss (Walbaum). Aquac Res. (1998) 29:6017. doi: 10.1046/j.1365-2109.1998.00251.x

43. Du ZY, Liu YJ, Tian LX, Wang JT, Wang Y, Liang GY. Effect of dietary lipid level on growth, feed utilization and body composition by juvenile grass carp (Ctenopharyngodon idella). Aquac Nutr. (2005) 11:13946. doi: 10.1111/j.1365-2095.2004.00333.x

44. Liao LM, Ren TJ, Chen W, Han YZ, Liu MC, Jiang ZQ, et al. Effects of dietary lipid level on growth performance, body composition and digestive enzymes activity of juvenile sea cucumber, Apostichopus japonicus. Aquac Res. (2015) 48:92-101. doi: 10.1111/are.12864

45. Ackman RG. Seafood lipids and fatty acids. Food Reviews International. (1990) 6:617-46. doi: 10.1080/87559129009540896

46. McClelland G, Zwingelstein G, Weber JM, Brichon G. Lipid composition of tissue and plasma in two Mediterranean fishes, the gilt-head sea bream (Chrysophyrys auratus) and the European seabass (Dicentrarchus labrax). Can J Fish Aquat Sci. (1995) 52:161-70. doi: 10.1139/f95-016

47. Zhan CN, Wang AM, Liu WB, Yang WP Yu YB, Lv LL, et al. Effects of dietary lipid levels on fat deposition, lipid metabolize enzyme and antioxidantic activities of Chelon haematocheilus. J Fishery Sci China. (2013) 20:10815. doi: 10.3724/SP.J.1118.2013.00108

48. Wang JY, Zhu SG, Xu CF. Biological Chemistry. Beijing: Higher Education Press (2002). 284 p.

49. Qin CJ, Chen LQ, Li EC, Xie BW, Yue XJ, Wang YM. A review: effects of dietary lipid levels on growth and lipid metabolism in fish fisheries science. Asian-Australas J Anim Sci. (2013) 32:485-91.
50. Li AX, Yuan XC, Liang XF, Liu LW Li J, Li B, et al. Adaptations of lipid metabolism and food intake in response to low and high lipid diets in juvenile grass carp (Ctenopharyngodon idellus). Aquac. (2016) 457:439. doi: 10.1016/j.aquaculture.2016.01.014

51. Leng XJ, Wu XF, Tian J, Li XQ, Guan L, Weng DC. Molecular cloning of fatty acid synthase from grass carp (Ctenopharyngodon idella) and the regulation of its expression by dietary fat level. Aquac Nutr. (2012) 18:5518. doi: 10.1111/j.1365-2095.2011.00917.x

52. Rollin X, Medale F, Gutieres S, Blanc D, Kaushik SJ. Short- and longterm nutritional modulation of acetyl-Co A carboxylase activity in selected tissues of rainbow trout (Oncorhynchus mykiss). BrJ Nutr. (2003) 89:80310. doi: 10.1079/BJN2003844

53. Wang AM, Han GM, Wei XJ, Liu B, Lv F, Feng GN, et al. Molecular cloning of fatty acid synthase from gift tilapia Oreochromis niloticus: response of its expression to refeeding and different lipid levels in diet. J Fisher China. (2010) 34:1113-20. doi: 10.3724/SP.J.1231.2010. 06781

54. Gou N, Chang ZG, Wei D, Ji H, Zhou J S. Effects of dietary lipid levels on growth, fatty acid composition, antioxidant status and lipid metabolism in juvenile Onychostoma macrolepis. Aquac Res. (2019) 50:113. doi: 10.1111/are.14295

55. Soengas JL. Contribution of glucose-and fatty acid sensing systems to the regulation of food intake in fish. Gen Comp Endocrinol. (2014) 205:3648. doi: 10.1016/j.ygcen.2014.01.015

Conflict of Interest: The authors declare that the research was conducted in the absence of any commercial or financial relationships that could be construed as a potential conflict of interest.

Copyright (C) 2021 Fan, Li, Zhang, Wu, Zheng, Wang and Wang. This is an openaccess article distributed under the terms of the Creative Commons Attribution License (CC BY). The use, distribution or reproduction in other forums is permitted, provided the original author(s) and the copyright owner(s) are credited and that the original publication in this journal is cited, in accordance with accepted academic practice. No use, distribution or reproduction is permitted which does not comply with these terms. 